Journal of Fundamental and Applied Sciences

ISSN 1112-9867

Available online at

http://www.jfas.info

\title{
CHARACTERIZATION OF CO-PRODUCTS OF THE PILOT DIGESTERS TO ANIMAL BIOMASS IN TUNISIA
}

\author{
Y. M'Sadak * and A. Ben M'Barek
}

Department of the Genius of the Horticultural Systems and the Natural Environment Higher Agronomic Institute of Chott-Mariem, University of Sousse, Tunisia

Received: 27 November 2014 / Accepted: 07 February 2015 / Published online: 08 February 2015

\begin{abstract}
This work consists in evaluating the Co-products of the biomethanisation applied to the animal biomass on the level of various types of digesters (experimental I, II, III and IV, rural and industrial).

This work made it possible to arise certain number of observations: The energy performances are more interesting in the case of the digesters powered with the avicolous droppings; the reduction of the polluting load as of SM is more important in the case of the industrial digester, whereas for the $\mathrm{BDO}_{5}$, it is in favor of the experimental digester II; The agronomic use of the secondary by-products proves very encouraging and powerful.
\end{abstract}

Keywords: Pilot digesters; Bovine dejections; Avicolous droppings; Biogas; Methacompost; Juice of process.

\section{INTRODUCTION}

Biomass is a field in constant increase and has a wide diversity of composition. Its operations for the production of energy, is particularly interesting because it also involved in the preservation of the environment [1-3]. In Tunisia, the performance of the Biogas effluents applied to intensive livestock were evaluated at different scales: Experimental [4], rural [5] and industrial [6].

Author Correspondence, e-mail: msadak.youssef@yahoo.fr

ICID: 1139456 
The biomethanisation is one of the biological processes which contributes to the degradation of the organic matters $(\mathrm{OM})$ died, vegetable or animal (preferably, not contaminated by pollutants or inert) by a microbial flora in anaerobe [7-10] and with their transformation into simple elements, gas and mineral [11-15].

Only the biodegradable fraction of $\mathrm{OM}$ is concerned by the biomethanisation. In absence of oxygen $\left(\mathrm{O}_{2}\right)$, it is degraded partially by the combined action several types of micro-organisms $[11,16]$, A succession of biological reactions leads to the formation of biogas (mainly compound of methane) [17,10,18] and of the solid and liquid digestates [19-22]. Biogas could be developed in electricity and heat, whereas the solid digestate (called methacompost) considered as deodorized compost, hygienized, discharged from carbon and rich in nitrogen quickly assimilable by the plants could be spread, inter alia, like manure of farm. The liquid digestate (called juice of process) could be also developed by spreading.

In the optics of the control of the conditions of the fermentaire medium for a better energy, environmental and agronomic valorization of the by-products of the biomethanisation, this study proposes, like main aim, the follow-up and the evaluation on the one hand, of the quantitative productivity of the biogas produced on an experimental scale starting from the poultry droppings (digesters I and II) and of the bovine dejections (digesters III and IV), and on the other hand, of the qualitative gas productivity (composition and calorific value) on the level of various types of digesters implemented (experimental, rural and industrial).

Moreover, it aims at the evaluation of the assessments of depollution of the animal biomasses treated by biomethanisation on the experimental and real plans, in terms of suspended matter (SM) and biological demand for oxygen ( $\left.\mathrm{BDO}_{5}\right)$.

In addition, the solid and liquid digestates, principal residues of the rural biomethanisation of the bovine biomass, were the subject of an appreciation of their agronomic interest except ground respectively like substrate of culture and fertilizer.

\section{MATERIALS AND METHODS}

\subsection{Various experimental devices}

\subsubsection{Pilot digesters of laboratory}

The experimental device, installed on the level of the laboratory "Biogas" of the Agricultural Professional Training Center of Bovine Breeding (A.P.T.C.B.B.) of Sidi Thabet (Tunisia), consists of four pilot digesters (Figure 1). 
Two digesters I and II differ only by their concentrations in dry matter (DM) which is about $6 \%$ on the level of the first and $8 \%$ in the second. The follow-up of these experimental digesters stressed especially on the effect of the variation of the rate of DM of the substrates treated by anaerobic digestion on the gas depollution and quantitative and qualitative productivities starting from the avicolous biomass.

The two experimental digesters III and IV differ from physicochemical parameters point of view. They were useful for the follow-up of the quantitative gas productivity starting from the bovine biomass.

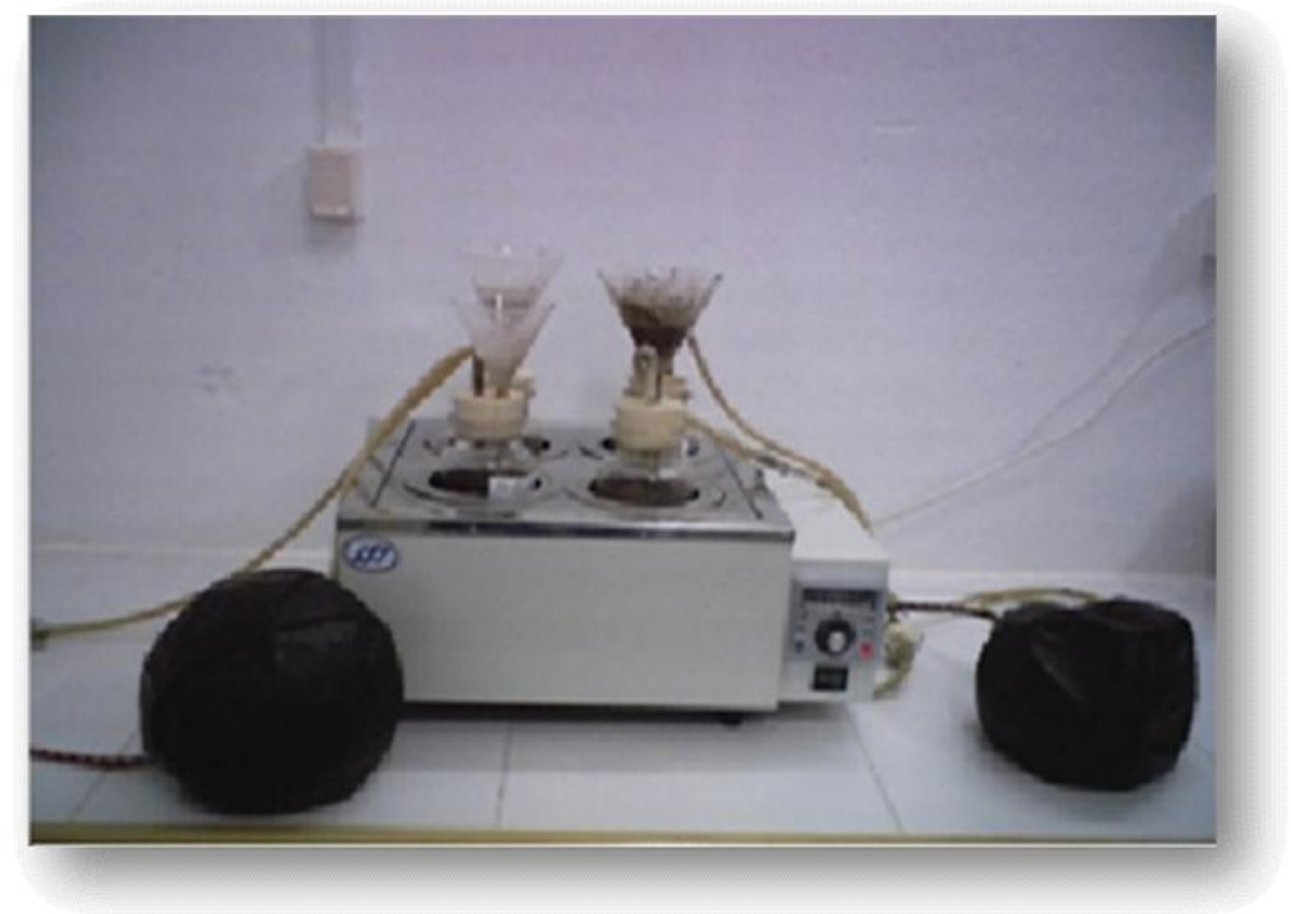

Fig.1. Pilot digesters of laboratory

Table 1 shows some general data on these two digesters tested.

Table 1. Criteria of differentiation enters the two experimental digesters III and IV

\begin{tabular}{|l|c|c|c|}
\hline Digesters & Bovine dungs used & Temperature $\left({ }^{\circ} \mathrm{C}\right)$ & Agitation \\
\hline Experimental III & Fresh black dungs & 25 & - \\
\hline Experimental IV & Fresh dungs & 35 & + \\
\hline
\end{tabular}




\subsubsection{Rural pilot digester}

It is a buried pilot digester (Figure 2), installed with the farm attached to the APTCBB. This rural digester is characterized by a very weak investment and a great simplicity, since it is, mainly, auto-builds and not using sophisticated equipment.

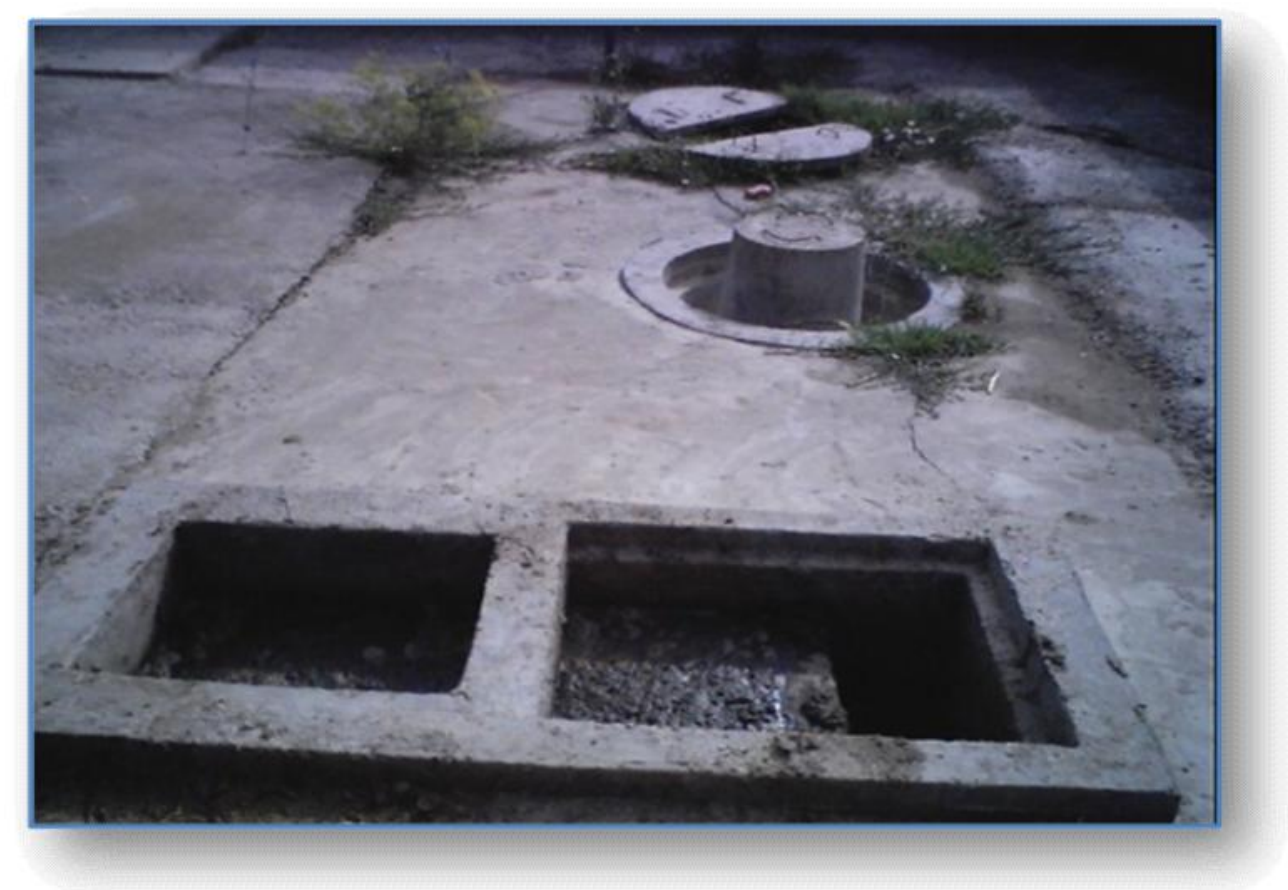

Fig.2. Rural pilot digester of Sidi Thabet

\subsubsection{Industrial pilot digester}

It is a pilot digester with cylindrical form (Figure 3), installed in a poultry farm in Hammam Sousse (Tunisia) since the year 2000. The installation is designed to treat four tons of fresh dejections daily, representing the day laborer production of an industrial avicolous breeding around 20000 layers.

The unit of biomethanisation installed has an environmental objective which consists in the reducing of the pollution generated by the avicolous droppings and an energy objective which consists to feed the generators and to satisfy the needs for the farm and the station in produced electrical energy.

Table 2 summarizes some characteristics relative to the various digesters implemented.

The quantities of each raw material introduced into the digesters considered are mentioned in Table 3. 


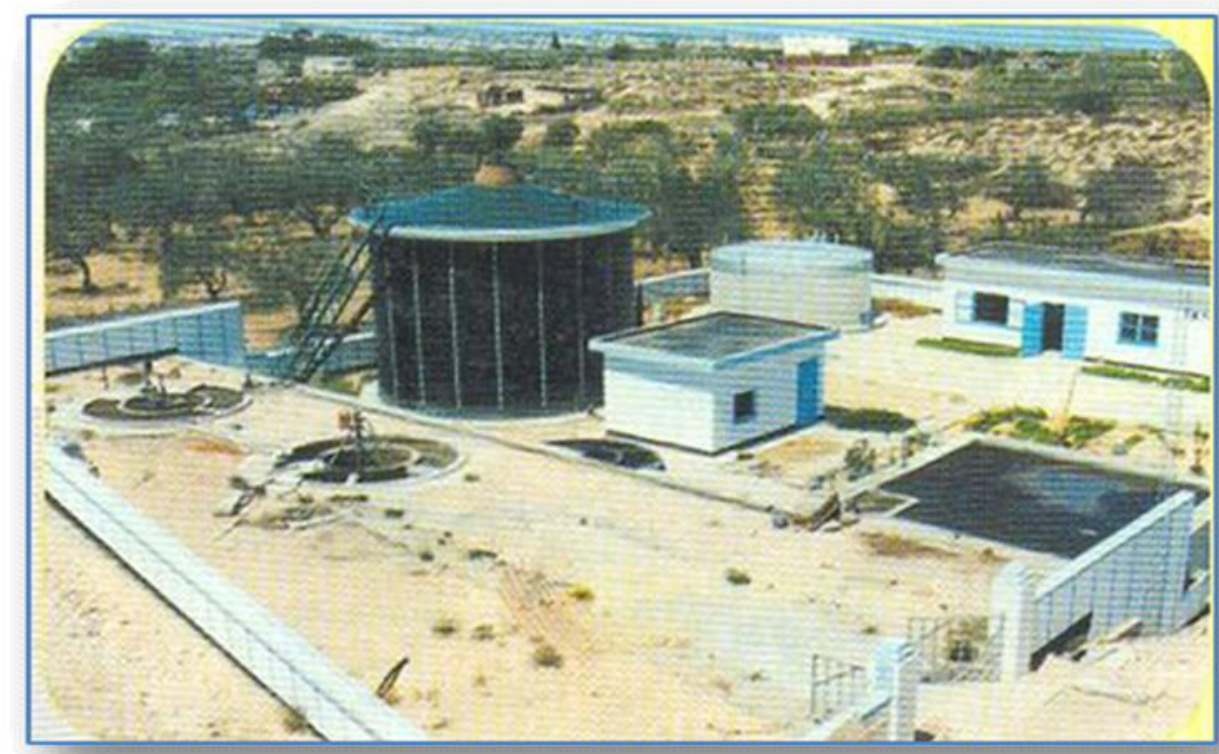

Fig.3. Industrial pilot digester of Hammam Sousse

Table 2. Summary of the general characteristics of the used digesters

\begin{tabular}{|c|c|c|c|c|c|}
\hline \multirow{2}{*}{\multicolumn{2}{|c|}{ Type of digester }} & \multicolumn{2}{|c|}{ Experimental } & \multirow{2}{*}{ Rural } & \multirow{2}{*}{ Industrial } \\
\hline & & I and II & III and IV & & \\
\hline \multirow{2}{*}{$\begin{array}{l}\text { Nature of } \\
\text { the } \\
\text { substrate }\end{array}$} & Substrate & $\begin{array}{l}\text { Avicolous } \\
\text { dropping }\end{array}$ & \multicolumn{2}{|c|}{ Fresh bovine dungs } & $\begin{array}{l}\text { Avicolous } \\
\text { dropping }\end{array}$ \\
\hline & Inoculum & \multicolumn{3}{|c|}{ Black bovine dungs } & - \\
\hline \multicolumn{2}{|c|}{ Capacity of the digester } & \multicolumn{2}{|c|}{$500 \mathrm{ml}$} & $6 \mathrm{~m}^{3}$ & $300 \mathrm{~m}^{3}$ \\
\hline \multirow{2}{*}{$\mathrm{DM}(\%)$} & Substrate & 20.9 & 31.5 & 31.5 & 20.9 \\
\hline & Inoculum & 4.0 & 9.4 & 9.4 & - \\
\hline \multirow{2}{*}{$\mathrm{pH}$} & Substrate & 8.7 & 6.5 & 6.5 & 8.7 \\
\hline & Inoculum & 7.2 & 7.2 & 7.2 & - \\
\hline
\end{tabular}


Table 3. Quantification of the inputs

\begin{tabular}{|c|c|c|c|}
\hline Type of the digester & Substrate (l) & Inoculum (l) & Water (l) \\
\hline Experimental I & 0.12 & 0.15 & 0.23 \\
\hline Experimental II & 0.17 & 0.15 & 0.18 \\
\hline Experimental III & 0.60 & 0.30 & 0.18 \\
\hline Experimental IV & 0.10 & - & 0.20 \\
\hline Rural & 2000 in the start + & 1000 & 0 in the start + \\
\hline Industrial & $50 /$ day & - & $6.66 \mathrm{~m}^{3}$ \\
\hline
\end{tabular}

\subsection{Evaluation of the energy performance of produced biogas}

The quantitative and qualitative follow-up of produced biogas is a paramount stage for a true characterization of the principal by-product of the biomethanisation, for an optimal valorization.

The quantitative analysis was carried out at the laboratory "Biogas" of the APTCBB, whereas the qualitative analysis has made at the test laboratory of the Tunisian Company of Industries of Refining (T.C.I.R.), located in Bizerte. This analysis understands a determination of the composition of biogas produces and its calorific value (CV).

Concerning the quantification, we had a vat filled with water (Figure 4) in which, we installed beakers graduated to recover gas produced (the gas will drive out water and take its place, from where; we can directly read the quantity produced starting from the graduations). The taking away of biogas was carried out by calling upon a simple system based on bladders of balloon as Figure 1 relating to the experimental digesters shows it.

For the analysis of the gas composition, we had recourse to the technique of Gas chromatography. This technique is suitable for the compounds gas or likely to be vaporized by heating without decomposition. The components determined by this method are the following: $\% \mathrm{CH}_{4}, \% \mathrm{CO}_{2}$ and $\% \mathrm{H}_{2} \mathrm{~S}$.

Moreover, we were also interested to the natural energy, by estimating the value of the lower calorific value noted LCV. The LCV is the energy resulting from combustion without taking account of the energy devoted to the vaporization of water. This energy is calculated when the water produced by combustion remains with the vapor state. 


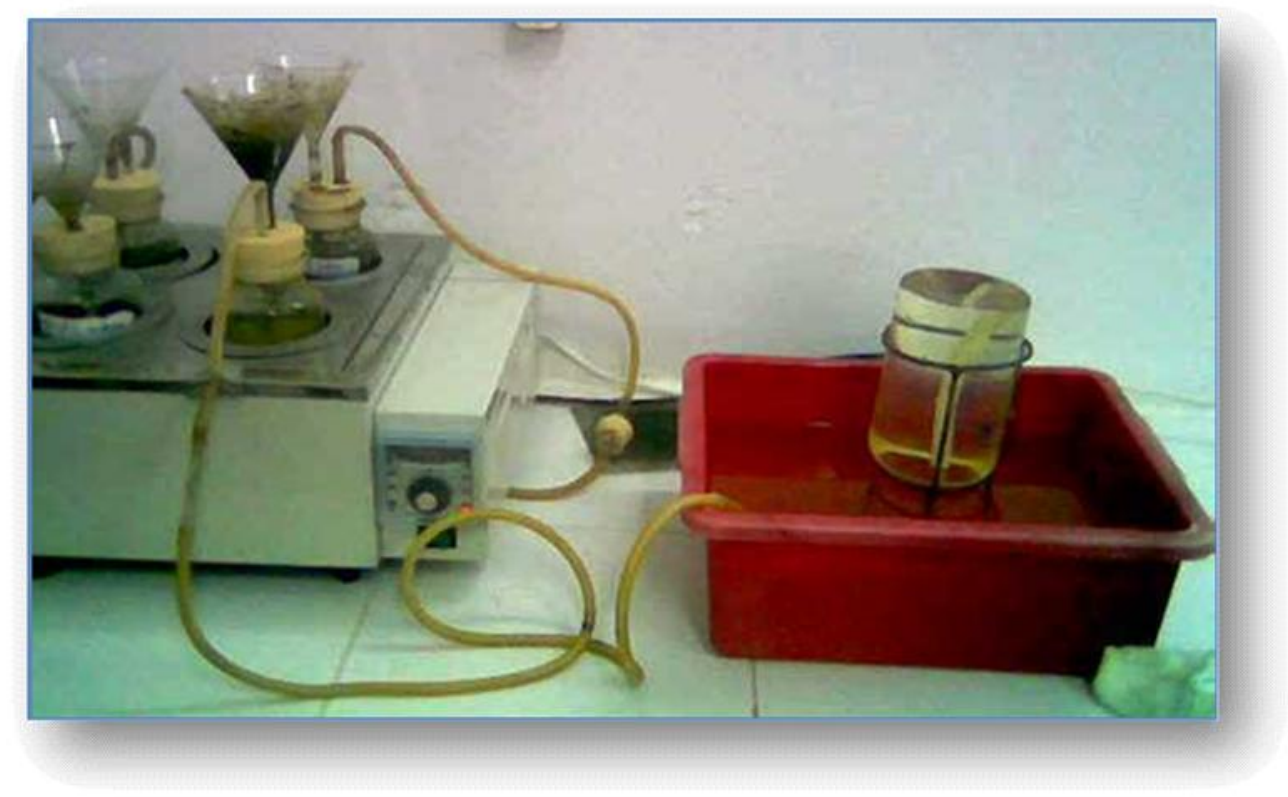

Fig.4. Adopted system of quantification of experimental biogas

\subsection{Evaluation of environmental performance of the digesters implemented}

The environmental parameters in which we were interested are relating to the polluting load $\left(\mathrm{SM}\right.$ and $\mathrm{BDO}_{5}$ ) of the digested matter coming from various digesters. The analysis were carried out at the laboratory "Biogas" of the APTCBB.

For SM, they correspond to the whole of mineral and/or organic particles present in natural or polluted water [23]. Their determination makes it possible to consider the biomass bacterial in the digester [24]. The analysis rests on the principle of quantifying of all the matters being able to be decantable after elimination of the major part of water by filtration and evaporation in the drying oven with $105^{\circ} \mathrm{C}$.

Concerning the $\mathrm{BDO}_{5}$, this parameter constitutes a good indicator of the biodegradable $\mathrm{OM}$ content of water during processes of purification. The principle of the measurement of the $\mathrm{BDO}_{5}$ rests on the quantification of $\mathrm{O}_{2}$ consumed after incubation during five days.

\subsection{Evaluation of the agronomic value of the produced digestats}

\subsubsection{Appreciation of the operating requirement of the methacompost like substrate of culture}

The evaluation of the agronomic value of the methacompost in a pure state or in mixture appeared using a bearing test on the sowing of seeds of pepper. The methacompost used in this test was taken after a residence time of 15 days in the rural digester, then dried for a period of four days. 
Three types of substrates were tested which are a pure peat (pilot), a pure methacompost and a mixture of $60 \%$ peat and $40 \%$ methacompost. The follow-up related to the behavior of the pepper seedlings installed in alveolate plates (growth in heightof the seedlings).

\subsubsection{Appreciation of the fertilizing capacity of the juice of process}

The fertilizing capacity of the juice of process is appreciated by using it to sprinkle seedlings of pepper already prepared in advance (sown in alveolate plates on the same support of reference which is the compost) while selecting 24 seedlings having homogeneous heights which will be the support of the experimentation. Then, we began the watering of the seedlings selected with the solutions prepared at a rate of a watering every 48 hours during 20 days, while taking the levellings cumulated in regular intervals of four days.

The solutions tested are: water (pilot), juice of concentrated process, then respectively diluted, at a rate of $75 \%$ and $25 \%$.

\section{RESULTS AND DISCUSSION}

\subsection{Quantitative and qualitative evaluation of the gas productivity}

\subsubsection{Results of the quantification of produced biogas}

In the studied case, when we speak about quantitative productivity of the biogas produced starting from the animal biomass in digesters of laboratory, there are two different scales: Large scales which correspond to the productivity recorded for the case of the avicolous droppings (Figure 5) and the smaller second correspondent with the case of bovine dungs (Figure 6).

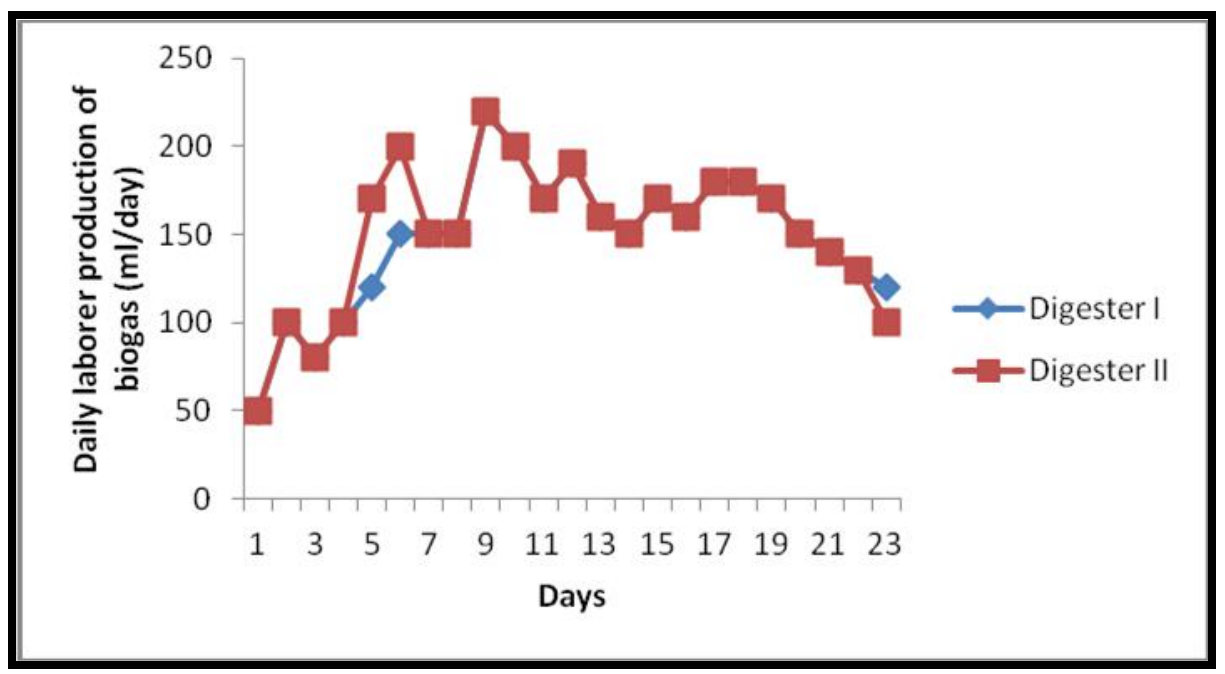

Fig.5. Evolution of the avicolous volume of biogas produced on the level of digesters I and II 
What makes it possible to conclude that the productivity of biogas depends on the type of $\mathrm{OM}$ methanized and the technology on supply power (or mode of digestion) of the digester. It is higher in the case of the avicolous biomass treated in a digester uninterrupted supplied.

The day laborer production of avicolous biogas is not constant. It fluctuated around a value average day laborer, which are about $142 \mathrm{ml}$ for the case of digester I (6\% DM), and around $147 \mathrm{ml}$ for the case of digester II (8\% DM).

The results obtained for two digesters I and II are in conformity with the bibliography which indicates an increase in the production of biogas with the increase in the concentration of DM [25]. According to the same author, the concentration in DM of the poultry droppings in a digester should not exceed $10 \%$. Beyond this value, the matter is dense and causes the methane arrested fermentation quickly.

The presence of various peaks could be explained by the existence of the fresh matters which do not arrive regularly at the level of the bacteria and their evacuation which is done before their complete decomposition.

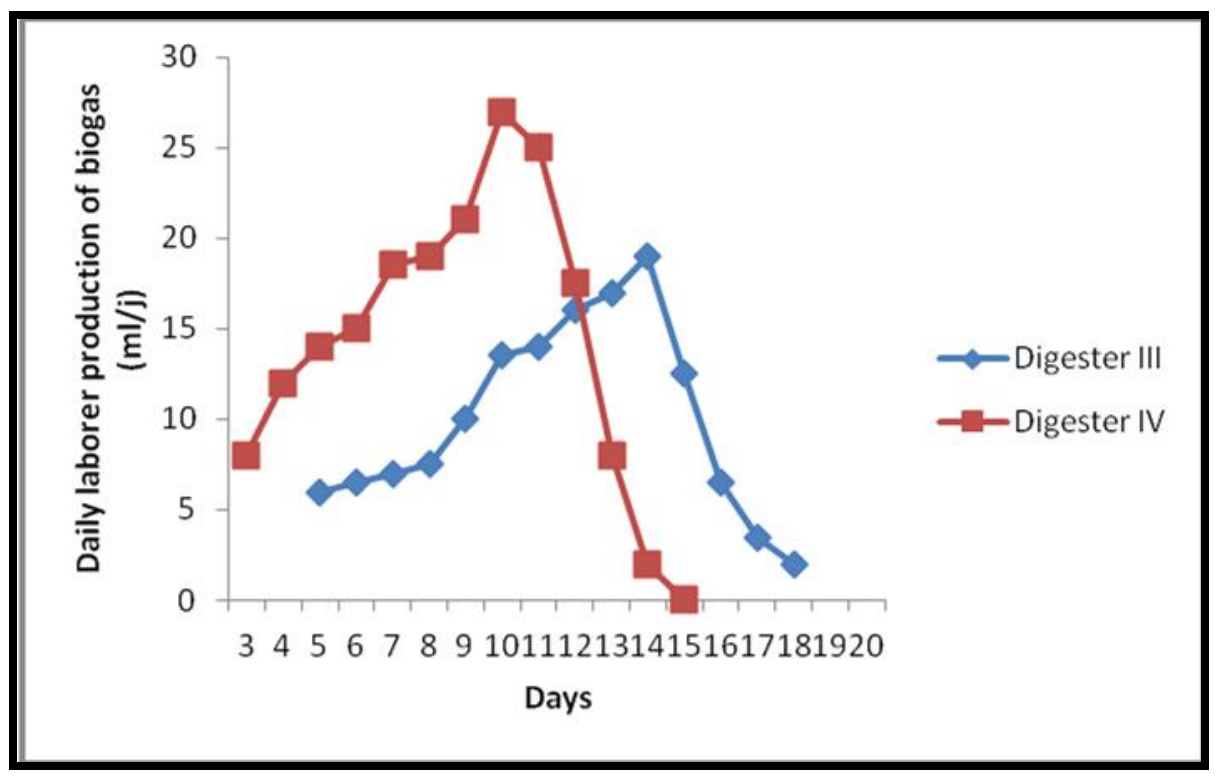

Fig.6. Evolution of the volume of bovine biogas produced on the level of digesters III and IV

The considerable combined effect of the temperature and agitation on the productivity of bovine biogas is more remarkable than the effect of the addition of the inoculum, from point of view speed and quantity of production. 
In this respect, let us announce that agitation makes it possible to release the gas bubbles starting from the deep layers, to maintain the homogeneity of the temperature at various levels and to avoid the consolidation of the crust on the surface of the digester. It supports, moreover, the provisioning of the bacteria of nutritive substances and their transport with the fresh substrate, lately introduced, from where, a clear improvement of the produced quantity. In terms of productivity, digester IV presented a total production of about $187 \mathrm{ml}$ with a peak of production corresponding to $27 \mathrm{ml} /$ day. For the case of digester III, it recorded a total equal to $141 \mathrm{ml}$ of biogas produced with a maximum of order of $19 \mathrm{ml} /$ day.

\subsubsection{Results of the qualitative follow-up of the gas productivity}

The biogas produced by the rural digester underwent a conditioning (filtration, reduction of moisture...), in the same way, industrial biogas underwent a treatment by purification by calling upon a desulphurization with the iron hematite. Purification consists in eliminating not only the elements traces like the steam, the hydrogen sulfide and the halogenous compounds, but also the carbonic gas, in order to enrich the concentration by methane biogas.

Concerning experimental biogas, no conditioning was implemented, in the same way, the qualitative follow-up was limited to the biogas produced on the level of the experimental digesters I and II.

\subsubsection{Gas composition}

The results of the analysis relating to the composition in major elements of the biogas produced by the digesters tested are given in Table 4.

The quality of biogas is evaluated primarily by the percentage of methane $\left(\mathrm{CH}_{4}\right)$ which it contains. A biogas is of as much better than its percentage out of methane is high [25].

Table 4. Expression of the results of the composition of produced biogas

\begin{tabular}{|c|c|c|c|c|}
\hline \multicolumn{2}{|c|}{ Type of digester } & $\mathrm{CH}_{4}(\%)$ & $\mathrm{CO}_{2}(\%)$ & $\mathrm{H}_{2} \mathrm{~S}(\%)$ \\
\hline \multicolumn{2}{|c|}{ Experimental I } & 63.3 & 20.0 & 16.18 \\
\hline \multirow{2}{*}{ Experimental II } & 63.4 & 30.0 & 5.89 \\
\hline \multirow{2}{*}{ Industrial } & Before treatment & 58.1 & 40.9 & - \\
\cline { 2 - 5 } & After treatment & 66.1 & 32.7 & - \\
\cline { 2 - 5 } & Before treatment & 60.0 & 30.0 & 10.00 \\
\cline { 2 - 5 } & After treatment & 75.0 & 25.0 & - \\
\hline
\end{tabular}


For the case of the experimental digesters, $\% \mathrm{CH}_{4}$ generally produces increased with the increase in the concentration in DM (while passing from 6 to 8\%). However, rise is negligible. It should be noted that the content methane is also influenced by other not followed parameters (report $\mathrm{C} / \mathrm{N} \ldots$... In the same way, $\% \mathrm{CO}_{2}$ also rose with the increase in the concentration in DM. This could be explained by the dissolution of ammonia in the form of ammonia, thus raising the value of the $\mathrm{pH}$, whereas after post-processing of rural biogas and industrial biogas, $\%$ of this element comes to decrease considerably. $\% \mathrm{H}_{2} \mathrm{~S}$ decreased with the rise in the concentration in DM under the adopted experimental conditions. However, it is advisable to announce that this parameter is generally less low than that raised. In the actual position, such a rate generates the phenomenon of corrosion and the purification of produced biogas proves strongly recommended before use.

The analysis of the results of the performance evaluation of post-processing carried out makes it possible to release that $\% \mathrm{CH}_{4}$ after conditioning increased by $8.0 \%$ (case of the rural digester) and by $15.0 \%$ (case of the industrial digester), which respectively gives outputs of purification of $13.8 \%$ and $25.0 \%$.

The results obtained show a certain effectiveness of the post-processing of the biogas which ensures a reduction in polluting elements more $\left(\mathrm{CO}_{2}, \mathrm{H}_{2} \mathrm{~S} \ldots\right)$ as well as an intensification in concentration of the $\mathrm{CH}_{4}$.

\subsubsection{Calorific value}

The energy results corresponding worthy of LCV, on the level of various digesters considered, are given in Table 5.

Table 5. Results relating to the calorific values

\begin{tabular}{|l|l|c|}
\hline \multicolumn{2}{|l|}{ Type of digesters } & LCV $\left(\mathrm{kcal} / \mathrm{Nm}^{3}\right)$ \\
\hline Experimental I & 5394 \\
\hline Experimental II & Before treatment & 5429 \\
\hline \multirow{2}{*}{ Rural } & After treatment & 4973 \\
\hline Industrial & Before treatment & 5210 \\
\cline { 2 - 3 } & After treatment & 5110 \\
\hline
\end{tabular}

It has a light increase in the LCV according to the concentration in DM in the case of the experimental digesters I and II. All the recorded calorific values are in conformity with those indicated by [26] which announces a fork generally lain between 5000 and 8500 
$\mathrm{kcal} / \mathrm{Nm}^{3}$.After purification, there is a clear improvement of the calorific value especially in the case of the industrial digester presenting an output equal to $25.0 \%$. We can say that industrial biogas produces present valid energy potentialities before and after purification.

The output of purification of the rural digester is equal to $4.8 \%$. This poor yield could be explained by the inefficiency of the process of conditioning implemented. Ultimately, it is advisable to more improve the output of purification of biogas to reach the theoretical maximum equal to $8500 \mathrm{kcal} / \mathrm{Nm}^{3}$ [26].

\subsection{Appreciation of the environmental and agronomic interests of the digestates}

\subsubsection{Establishment of the assessments of depollution as of the $\mathrm{SM}$ and of the $\mathrm{BDO}_{5}$}

Figure 7 gathers the results relating to the assessments of depollution as of SM and of the $\mathrm{BDO}_{5}$ in the various types of digesters used except for the experimental digesters III and IV not followed on the depollution plan.

On an experimental scale, the consistency of the digesters in DM influences considerably the assessments of depollution as of $\mathrm{SM}$ and of the $\mathrm{BDO}_{5}$, which increase with the rise in the rate of DM of the introduced substrates. This observation is valid provided that the concentration in DM does not exceed $10 \%$ [19], which is confirmed by results raised for experimental digester II to $8 \% \mathrm{DM}$, which presents assessments of depollution better than those obtained for the case of the experimental digester I which recorded non satisfactory assessments of depollution, even, relatively satisfactory. Even the results corresponding to the assessments of depollution of digester II deserve to be improved, and in particular, \% of reduction of the polluting load as of SM.

For the case of the rural and industrial digesters, SM are them in continuous decrease throughout the advance of the substrate during the process of biomethanisation. On a rural scale, and while going from the first to the second mixture, there is an improvement of the reduction of the polluting load in SM estimated at $29.0 \%$ and which could be explained by the good biological breakdown of OM. 


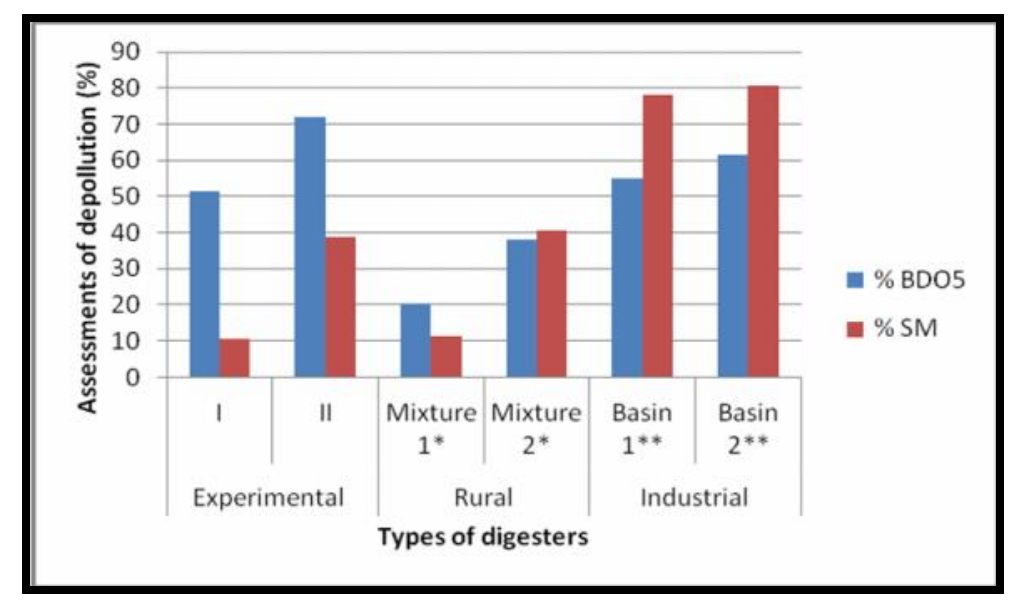

(*) Mixture 1: Mixture initially introduced Mixture 2: Mixture introduced later

(**) Basin 1: Basin of the digested droppings Basin 2: Mud tank

Fig.7. Variation of the rates of depollution on different scales of production

This biological breakdown is better in the case of the industrial digester whose reduction is higher than $80 \%$ as of SM on the level of the mud tank and it is largely due to the practiced system of digestion, with fixed cells, calling upon 6000 bricks of 12 laid out in superposition and who allows a good retention of the bacteria methanogens inside the digester. Such a system does not exist on the level of the experimental digesters, where the renewal by supplyextraction reduces partly the methanogen population, from where; the assessment of depollution is less in the case of experimental digestion.

On the other hand, concerning the $\mathrm{BDO}_{5}$, the industrial digester present of the relatively satisfactory assessments of depollution and the reduction of the polluting load exceed $55 \%$ in the two basins. The results obtained are higher than those retained for the rural digester which presents insufficient and nonsatisfactory assessments of depollution for the two mixtures considered.

\subsubsection{Agronomic valorization except ground of the methacompost like substrate of culture}

By comparison between the various substrates of culture (pure or in mixture), the growth in height of the seedlings of pepper is almost identical for the seedlings installed on peat and methacompost at the pure state (Figure 8). But, the seedlings installed on methacompost presented stems hails, sensitive and some were burned and end up fading.

The peat mixed with methacompost (at a rate of $60 \%$ peat and $40 \%$ methacompost) gives a faster growth and higher heights of the seedlings without presenting vegetative anomalies.

The produced methacompost cannot be regarded as adequate substrate in a pure state, because of its insufficient porosity of ventilation, which justifies its mixture according to adequate proportions, with the peat which has a porosity of higher ventilation. 
These preliminary results are extremely interesting (being given the possibility of incorporation of the methacompost at a rate of $40 \%$ with the peat) and deserve other investigations before being applied.

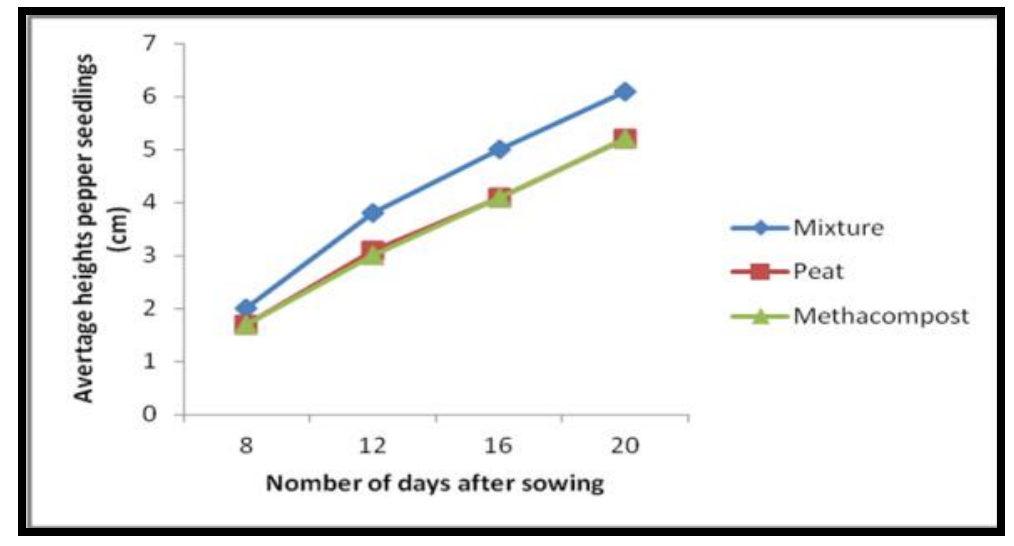

Fig.8. Growth in height of the pepper seedlings installed on various substrates

\subsubsection{Agronomic valorization except ground of the juice of process like fertilizer}

The juice of process used in a concentrated state for the watering of the seedlings of pepper allowed a considerable growth in height reaching $8 \mathrm{~cm}$ in 20 days, but it is necessary to evoke that several seedlings end up by fading suddenly. The same observations were raised for watering with a solution made up of $75 \%$ Juice of Process and 25\% Water (Figure 9) as well from growth point of view of the seedlings as sudden fading. On the other hand, a solution made up of $25 \%$ Juice of Process and $75 \%$ Water, allow a better growth without presence of anomalies of fading. Such results deserve to be confirmed by testing in parallel the report of dilution $1 / 2$, to study the possibility of fertigation of the seedlings with this last report.

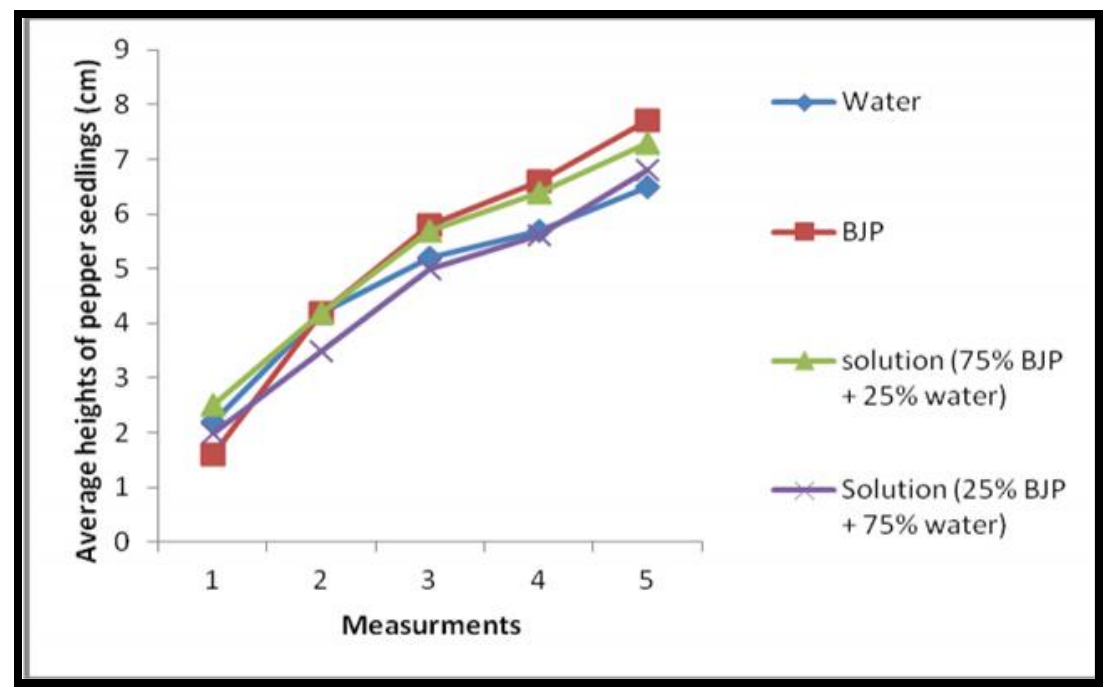

Fig.9. Test of growth of the pepper plants sprinkled with various solutions 


\section{CONCLUSION}

Once the completed biomethanisation, in its simplest application, two By-products are obtained: biogas like produces principal and an effluent (residue) treaty called Digestatesundergoing a separation of the phases leading to two fractions, one solid (Methacompost) and the other liquidates (Juice of Process).

In the light of the results obtained at the time of this study referring to the characterization of the By-products of the biomethanisation, for an energy of produced biogas, environmental valorization (reduction of the polluting load) of the animal manure (avicolous droppings and bovine dungs) digested in various types of digesters (experimental, rural and industrial) and agronomic valorization of the residues (methacompost and juice of process), we could draw some interesting observations on:

- The combined effect of the mode of digestion (uninterrupted or into discontinuous) and of the nature of the substrate (avicolous or bovine) on the quantitative energy performances of produced experimental biogas. The gas productivity is higher in the case of the digesters supplied uninterrupted with the avicolous droppings.

- The effect of the concentration in DM as well on the reduction of the polluting load of point of view $\mathrm{SM}$ and $\mathrm{BDO}_{5}$ as on the qualitative energy performances (gas composition and calorific value) of experimental biogas produced.

- The evaluation of environmental performance on a real scale (case of the rural and industrial digesters) watch an unquestionable interest on the reduction plans as of $\mathrm{SM}$ and of the $\mathrm{BDO}_{5}$ in favor of the industrial digester. The assessments of depollution obtained are weak to relatively weak for the case of the rural digester, but relatively satisfactory to satisfactory for the case of the industrial digester.

- The post-processing of rural or industrial biogas makes it possible to more increase its energy potentialities on the plans $\% \mathrm{CH}_{4}$ and $\mathrm{LCV}$ of $25 \%$ in the case of the industrial digester.

- The use of the peat in mixture with methacompost, at a rate of $40 \%$, as substrate of culture except ground proves very encouraging and powerful with respect to the growth in height of the seedlings of pepper.

- The fertilizing powers of the juices of process are very interesting, in particular, that diluted to water $75 \%$. However, the results obtained are only preliminary and they deserve to be 
considered with prudence, because of certain vegetative anomalies raised in the case of more concentrated juices (from 75 to $100 \%$ ).

\section{REFERENCES}

[1] Afilal M.E., Moncif M., Benyamna A. Valorisation des déchets organiques par fermentation méthanique, Revue des Energies Renouvelables CER'07 Oujda (2007) : 9-12. www.cder.dz/download/cer07_2.pdf

[2] Afilal M.E., Bakx A., Belakhdar N., Membrez Y. Evaluation of the biogas potential of organic waste in the northern provinces of Morocco, Revue des Energies Renouvelables Vol. $13 \mathrm{~N}^{\circ} 2$ (2010) : 249 - 255.

www.cder.dz/download/Art13-2_5.pdf

[3] Afilal M.E., Belkhadir N., Daoudi H., Elasri O. Fermentation méthanique des différents substrats organiques, J. Mater. Environ. Sci. 4 (1) (2013) : 11-16. www.jmaterenvironsci.com/Document/vol4/2-JMES-190-2012-Afilal.pdf

[4] M'Sadak Y., Ben M'Barek A., Zoghlami R.I. Diagnostics environnemental et énergétique des digesteurs anaérobies expérimentaux des fientes avicoles, Revue Nature \& Technologie, Janvier 2013, Numéro 8 (C) : 19-26. www.univ-chlef.dz/revuenatec/Art_08_C_03.pdf

[5] M'Sadak Y., Ben M'Barek A. Energy, environmental and agronomic valorizations of the rural biomethanisation of the bovine biomass, International Journal of Innovation and Applied Studies (IJIAS), October 2013, Vol. 4, No 2: 343-352. www.issrjournals.org/ijias/fr/authid.php?id=612

[6] M'Sadak Y., Zoghlami R.I. Caractérisations physico-chimique, environnementale et énergétique de la biométhanisation industrielle avicole en Tunisie semi-aride, Algerian Journal of Arid Environment (AJAE), Décembre 2012 : Vol. 2 No 2 : 16-27.

www.univ-ouargla.dz/Pagesweb/PressUniversitaire/doc/.../E020202.pdf

[7] Almoustapha O., Millogo-Rasolodimby J. Production de biogaz et de compost à partir de eichhorniacrassipes, (mart) solms-laub (pontederiaceae) pour un développement durable en Afrique sahélienne, Revue Vertigo, Septembre 2006 : Vol. 7, No 2.

http://vertigo.revues.org/2221; DOI : 10.4000/vertigo.2221

[8] APESA. Méthanisation et production de biogaz: État de l'art (2009) 37 p. www.apesa.asso.fr/iso_album/etat_de_1_art_methanisation-biogaz.pdf

[9] ARENE, ORDIF. Quelle place pour la méthanisation des déchets organiques en Ile-deFrance?, Étude réalisée pour le compte de l'ORDIF (Office Régional de Développement des 
Iles de France) et de l'ARENE (Agence Régionale de l'Environnement et des Nouvelles Énergies) par le Bureau d'Etudes SOLAGRO (2003) $31 \quad$ p. www.ordif.com/public/document.srv?id=6989

[10] Callaghan F.J., Wase D.A.J., Thayanithy K., Forster C.F. Co-digestion of waste organic solids: batch studies, Bioresource Technology 67 (1999): 117-122.

[11] Chynowetha D.P., Owensa J.M., Legrand R. Renewable methane from anaerobic digestion of biomass, Renewable Energy 22 (2002): 1-8.

[12] Basset Y., Gosset T. Atelier $N^{\circ} 1$ : La Biométhanisation, Journée Technique de Veolia Environnement, Espace Tamarun, Les Salines (2008) : 23 p.

[13] Liu C.F., Yuan X. zh., Zeng G.M., Li W.W., Li J. Prediction of methane yield at optimum $\mathrm{pH}$ for anaerobic digestion of organic fraction of municipal solid waste, Bioresource Technology 99 (2008): 882-888.

[14] RECORD. Méthanisation des déchets organiques. Étude bibliographique, n 01-0408/1A (2003) : 194 p.

\section{$\underline{\text { www.emse.fr/tice/uved/gidem/res/record_methanisation.pdf }}$}

[15] Toerien D.F., Hattingh W.H.J. Anaerobic Digestion: The Microbiology of Anaerobic Digestion, Water Research 3 (1969): 385-416.

[16] Karagiannidis A., Perkoulidis G.A. Multi-criteria ranking of different technologies for the anaerobic digestion for energy recovery of the organic fraction of municipal solid wastes, Bioresource Technology 100 (2009): 2355-2360.

[17] Shiralipour A., Smith P.H. Conversion of biomass into methane gas, Biomass 6 (1-2) (1984): 85-92.

[18] Inoue S., Tsukahara K., Sawayama S. Analysis of Effluent after Anaerobic Digestion of Liquid Phase Separated from Liquidized Garbage, Journal of Bioscience and Bioengineering 93 (6) (2002): 607-609.

[19] Pouech Ph., Coudure R., Marcato C.E. Intérêt de la Co-digestion pour la valorisation des lisiers et le traitement de déchets fermentescibles à l'échelle d'un territoire, Journées Recherche Porcine 37 (2005) : 39-44.

www.journees-recherche-porcine.com/texte/2005/05Env./env0506.pdf

[20] Saidi A., Abada B. La biométhanisation : une solution pour un développement durable, Revue des Énergies Renouvelables: CER'07 Oujda (2007): 31-35. www.cder.dz/download/cer07_7.pdf 
[21] Tambone F., Genevini P., D’ Imporzano G., Adani F. Assessing amendment properties of digestate by studying the organic matter composition and the degree of biological stability during the anaerobic digestion of the organic fraction of MSW, Bioresource Technology 100 (2009): 3140-3142.

[22] Karellas S., Boukis I., Kontopoulos G. Development of an investment decision tool for biogas production from agricultural waste, Renewable and Sustainable Energy Reviews 14 (2010): 1273-1282.

[23] Ramade F. Dictionnaire encyclopédique de l'écologie et des sciences de l'environnement, Édiscience internationale, Paris (1993) : 822 p.

www.dicoland.com/fr/

[24] Moletta R. Contrôle et conduite des digesteurs anaérobies, Revue des Sciences de l'eau 2 (1989) : 265-293.

http://nelson.cen.umontreal.ca/revue/rseau/1989/v2/n2/705031ar.pdf

[25] Akrout J. Étude énergétique de la fermentation méthanique des fientes de volailles: Optimisation des facteurs influents et modélisation du système, Doctorat de Spécialisation, École Nationale des Ingénieurs de Tunis (1992) : 143 p.

[26] Monzambe M. La problématique de la biométhanisation en République Démocratique du Congo, Université du Québec (2002) : 38 p.

classiques.uqac.ca/.../monzambe.../biomethanisation/biomethanisation.pd...

\section{How to cite this article}

M'Sadak Y, Ben M'Barek A. Characterization of co-products of the pilot digesters to animal biomass in Tunisia. J Fundam Appl Sci. 2015, 7(2), 185-202. 